\title{
On the origin and systematics of the northern African wood mouse (Apodemus sylvaticus) populations: a comparative study of mtDNA restriction patterns
}

\author{
R.M. Libois, J.R. Michaux, M.G. Ramalhinho, C. Maurois, and M. Sarà
}

\begin{abstract}
Conflicting hypotheses have been formulated regarding the origin of wood mouse (Apodemus sylvaticus) populations in northern Africa. In this study, the mtDNA restriction patterns of mice $(n=28)$ collected in Tunisia and Morocco are compared with those of representatives from southern Europe $(n=102)$. The neighbour-joining tree confirms the existence of the three lineages previously found in the Mediterranean area: western, Tyrrhenian-Balkan, and Sicilian. The western group is isolated from the two others, with bootstrap values of 89 and $95 \%$. Northern African patterns are included in the western group. Their variability is low, the same pattern being shared by five Tunisian and all Moroccan animals ( $n=18$ ), caught either in the north of the country (Cap Spartel) or in the south (Marrakech). This implies that northern African wood mouse populations have a southwestern European origin and that their presence in the region is probably recent, which corresponds to both paleontological data and the hypothesis of anthropogenic introduction.
\end{abstract}

Résumé : Des hypothèses contradictoires ont été formulées pour expliquer l'origine des populations nord-africaines de Mulots sylvestres (Apodemus sylvaticus). Cette note compare les patrons de restriction de l'ADN mitochondrial de 28 animaux capturés en Tunisie et au Maroc avec ceux de 102 individus du sud de l'Europe. L'arbre phylogénétique construit selon la méthode " neighbor joining » confirme l'existence des trois groupes trouvés précédemment dans le bassin méditerranéen : un groupe occidental, un groupe tyrrhéno-balkanique et un groupe sicilien. La séparation des groupes tyrrhéno-balkanique et sicilien de la lignée occidentale est fortement soutenue par des valeurs de bootstrap de 89 et $95 \%$, respectivement. Les patrons nord-africains se rattachent au groupe occidental. Leur variabilité est très faible, le même patron étant partagé par cinq animaux tunisiens et par tous les mulots marocains $(n=18)$, qu'ils proviennent du nord (Cap Spartel) ou du sud (Marrakech) du pays. Ces observations impliquent que les mulots d'Afrique du Nord prennent leur origine en Europe du sud-ouest et que leur présence en Afrique est probablement récente, ce qui correspond aux données paléontologiques ainsi qu'à l'hypothèse d'une introduction d'origine anthropique.

\section{Introduction}

Recently, the phylogeography of several western Palearctic species has been explored with success (e.g., Michaux et al. 1998a, 1998b; Santucci et al. 1998; Taberlet et al. 1998; Durand et al. 1999; Hewitt 1999; Engelbrecht et al. 2000); he existence of suture zones that are common to several species in spite of their different postglacial recolonization ?atterns has been demonstrated and the role of the Mediteranean peninsulas as glacial refuges and reservoirs has been sstablished. However, with the exception of Castella et al.
(2000), no studies on the origin of species whose distribution area includes North Africa have been reported (Demesure et al. 1996; Dumolin-Lapègue et al. 1997). Nevertheless, exchanges surely took place in the Mediterranean realm, including North Africa, that can explain the presence of several species on both continents as well as on Mediterranean islands. Some of these were probably due to human economic activity that occurred throughout the Holocene period between European and African coasts of the Mediterranean as well as between these continents and islands (Vigne 1994). Most of these involve anthropophilic mammals such

Received December 15, 2000. Accepted June 8, 2001. Published on the NRC Research Press Web site at http://cjz.nrc.ca on
August 15, 2001 .

R.M. Libois. 1,2 Museu Zoológico e Antropológico, Universidade de Lisboa, Rua da Escola Politécnica, 58, P 1269-102, Lisboa, Portugal, and Unité de recherches zoogéographiques, Institut de Zoologie, Université de Liège, Quai Van Beneden, 22, B-4020, Liège, Belgium. J.R. Michaux and C. Maurois. Unité de recherches zoogéographiques, Institut de Zoologie, Université de Liège, Quai Van
Beneden, 22, B-4020, Liège, Belgium.

M.G. Ramalhinho. Centro de Biologia Ambiental, Museu Zoológico e Antropológico, Universidade de Lisboa, Rua da Escola Politécnica, 58, P 1269-102, Lisboa, Portugal.

M. Sarà. Dipartimento di Biologia animale, Università di Palermo, Via Archirafi,18, I 90123 Palermo, Italy.

${ }^{1}$ Corresponding author (e-mail: Roland.Libois@ulg.ac.be).

${ }^{2}$ Address for correspondence: Institut de Zoologie, Quai Van Beneden, 22, B-4020, Liège, Belgium. 
Fig. 1. Map of the western Mediterranean area illustrating the four hypotheses examined about the origin of the wood mouse (Apodemus sylvaticus) in North Africa (see the text).

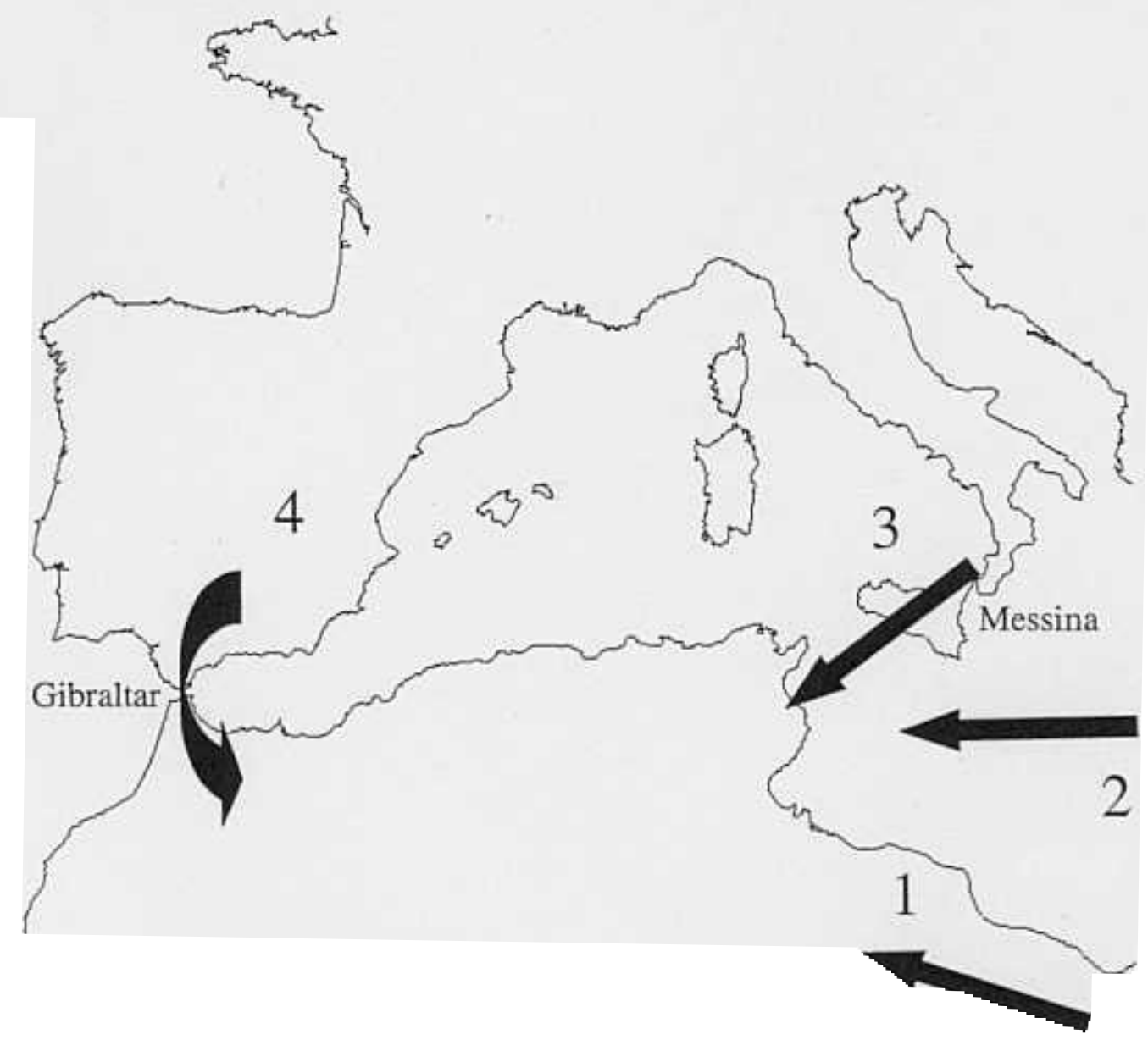

as the dormouse (Eliomys quercinus) and shrews (Crocidura suaveolens and Crocidura russula) in the late Neolithic period and the house mouse (Mus domesticus) and black rat (Rattus rattus) during the Bronze Age and Roman period, respectively (Sanges and Alcover 1980; Vigne 1983; Reumer and Sanders 1984). Similarly, other species such as the Egyptian mongoose (Herpestes ichneumon), common genet (Genetta genetta), and Algerian hedgehog (Atelerix algirus) were introduced into Europe from North Africa. Indeed, no subfossil records of these species are known in Europe before the Holocene, while their presence in Africa is reported since the Late Pleistocene (Kurten 1968; Holz and Niethammer 1990; Kowalski and Rzebik-Kowalska 1991).

The wood mouse (Apodemus sylvaticus) was also introduced into the main islands; its geographic origin has been recently discussed (Michaux et al. 1996a, 1998a, 1998b). In North Africa, subfossil findings are not known before 5000 4300 years ago (2950-2300 B.C.; Jaeger 1975), and different hypotheses (Fig. 1) have been formulated to explain its presence in the Maghreb (i.e., the Mediterranean part of Tunisia, Morocco, and Algeria):

1. It arrived through a natural colonization process from populations established in the Near East (Fig. 1). At the end of the last glaciation, the present desert regions of northern Egypt and Libya were not arid (Groves and Di Castri 1991; Blondel and Vigne 1993), allowing the westward migration of several mammalian species, possibly including A. sylvaticus (Arambourg 1962; Kowalski and Rzebik-Kowalska 1991;
Blondel and Vigne 1993). This hypothesis is the one st ported by Saint Girons (1972) and Thaler (1973).

2. It arrived through incidental human introductions. It possible that wood mice were transported with animal or I man food from the Near East.

3. The more likely scenario is that it was introduced humans from regions closest to North Africa, e.g., Sicily the Strait of Gibraltar. Indeed, archeozoological (Kowal and Rzebic-Kowalska; Jaeger 1975) and archeological (Car 1990) studies attest to contacts between human populati from North Africa and southern Spain and Sicily since early Paleolithic.

The first two scenarios (natural vs. human introducti are in agreement with paleontological data. However, $\mathrm{N}$. Filippucci (personal communication) doubts the natural e ern origin because it seems that ecoclimatic condition southeastern Turkey, Lebanon, and Israel were never fav able to the presence of $A$. sylvaticus, thus hindering its sage through this region. Apodemus sylvaticus is replace the Near East by other species more adapted to a dry clir such as Apodemus mystacinus or Apodemus hermone (Filippucci et al. 1989, 1996). This assumption is stren ened by the occurrence of two subspecies of an Apoder linked flea in North African wood mice that is not foun the eastern Mediterranean area: Leptopsylla taschent amitina lives in the Iberian Peninsula, southern Fra Morocco, and western Algeria, whereas L. t. calamana 1 more easterly range covering Sicily, Corsica, and penin: 
Fig. 2. Map of wood mouse sampling localities (๑) in the western Mediterranean area. For an explanation of the alphanumeric codes see Table 1. Some North African localities mentioned in the text but where no animals were trapped are also shown on the map ( $\square$ ). Localities are as follows: 1, Algiers; 2, Boulemane; 3, Chaouen; 4, Marrakech; 5, Tangier; 6, Temmerkennit; 7, Toubkal Massif.

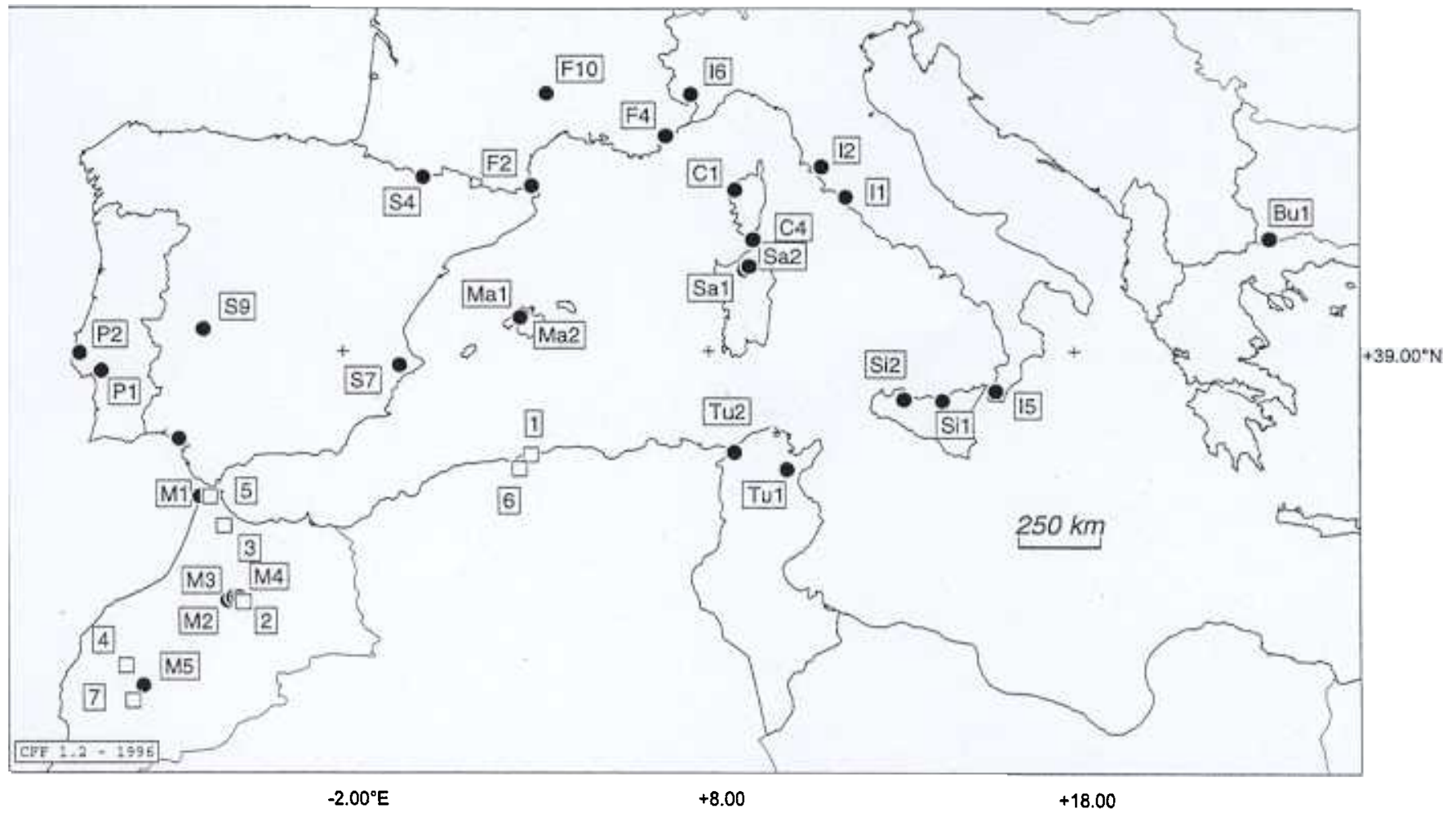

Italy as well as Tunisia and eastern Algeria (Beaucournu and Launay 1990). This suggests that North African wood mice may have a double European origin.

Morphologically, the North African wood mouse has long been considered distinguishable from its European relatives, being first described as Mus hayi Waterhouse, 1837. In 1886, Kobelt considered it to be a subspecies of Mus sylvaticus, an opinion supported by Saint Leger (1931) and Heim de Balsac (1936). In 1963, two new subspecies were described by Saint Girons and Van Bree (1963), a small one with large tooth rows, Apodemus sylvaticus ifranensis, and a larger one with relatively small tooth rows, $A$. s. rufescens.

Recently, Sarà and Casamento (1995), after accounting for allometric and nongeographical variation, reported that Algerian and Tunisian wood mice were morphometrically closer to those of the Italian peninsula than to those from Sicily and surrounding islands (Malta, Pantelleria, Marettimo, Favignana, etc.). Furthermore, they showed the peculiar status of the Sicilian mice, later confirmed by mtDNA analysis (Michaux et al. 1998b). This may suggest that North Africa has been colonized directly from northern or central Italy and not via Sicily, or that another colonization event occurred in Sicily after the passage of mice to North Africa. However, we must point out that in the wood mouse, morphological differentiation related to allometric change seems to be independent of the mtDNA characteristics of populations. Indeed, considerable size variation has been reported in populations with the same origin. The insular populations of Elba, Porquerolles, and Ibiza are probably the most illustrative examples (Libois and Fons 1990; Michaux et al. 1996b, 1998a).

In the present paper, the genetic variability of mtDNA in North African wood mice is described and populations are compared with those from western Europe and Italy previously studied (Michaux et al. 1996a, 1998a, 1998b). In this way, we intend to clarify whether North African wood mouse populations are monophyletic or polyphyletic. With respect to the latter possibility, we test if subdivision matches the recognized subspecies or is congruent with the doublecolonization hypothesis $(3+4$ in Fig. 1$)$.

\section{Materials and methods}

A total of 28 wood mice were trapped in North Africa in baited Manufrance or Sherman traps. Three regions were sampled, depending on the distribution of the subspecies: $(i)$ the Mediterranean belt in Tunisia and Morocco, mostly near Tangier (locus typicus of Apodemus sylvaticus hayi); (ii) forests between Ifrane and Boulemane in the Middle Atlas Mountains, Morocco (locus typicus of A. s. ifranensis) and in Azrou, the supposed boundary between the ranges of $A$. s. hayi and A. s. ifranensis (Saint Girons and Van Bree 1963; Saint Girons 1972); and (iii) the Toubkal massif near Taddert in the High Atlas Mountains, where A. s. rufescens is present, according to Saint Girons and Van Bree (1963).

Previously published data (Michaux et al. 1996a, 1998a, 1998b) from the European part of the western Mediterranean area were also included, as well as two specimens of the yellow-necked field mouse (Apodemus flavicollis) as outgroups. The geographic origin of the animals is illustrated in Fig. 2 and detailed in Table 1.

Mitochondrial DNA was isolated and processed with two restriction endonucleases as described in Michaux et al. (1996a). All distinctive mtDNA restriction fragment patterns were assigned a number when produced by $R s a \mathrm{I}$ or an alphabetical code when produced by HaeIII. Each animal was thus assigned an alphanumeric code. All specimens with the same composite restriction pattern were considered to have the same mtDNA haplotype.

Genetic distances were computed using Nei and Li's (1979) index of nucleotide sequence divergence, $p$. A neighbour-joining tree 
Table 1. Geographic coordinates and codes for trapping localities.

\begin{tabular}{|c|c|c|c|c|c|}
\hline Locality & $\begin{array}{l}\text { Locality } \\
\text { code }\end{array}$ & $\begin{array}{l}\text { Latitude } \\
\text { (1/00th deg.) }\end{array}$ & $\begin{array}{l}\text { Longitude } \\
\text { (1/00th deg.) }\end{array}$ & $\begin{array}{l}\text { No. of } \\
\text { animals }\end{array}$ & Date \\
\hline \multicolumn{6}{|l|}{ Bulgaria } \\
\hline Petric & Bu1 & 41.41 & 23.35 & & November 1995 \\
\hline \multicolumn{6}{|l|}{ France } \\
\hline Banyuls sur Mer & F2 & 42.50 & 3.13 & 6 & February 1993 \\
\hline Estérel & F4 & 43.51 & 6.81 & 4 & May 1994 \\
\hline Ispagnac & F10 & 44.37 & 3.53 & 2 & February 1996 \\
\hline \multicolumn{6}{|l|}{ Corsica } \\
\hline Galeria & $\mathrm{C} 1$ & 42.40 & 8.71 & 10 & April 1993 \\
\hline Bonifacio & C4 & 41.38 & 9.21 & 3 & April 1995 \\
\hline \multicolumn{6}{|l|}{ Italy } \\
\hline Tarquinia & I1 & 42.26 & 11.75 & 15 & December 1992 \\
\hline Grosseto & 12 & 42.88 & 11.09 & 2 & December 1992 \\
\hline Gambarie & 15 & 38.14 & 15.87 & 4 & January 1994 \\
\hline Cuneo & I6 & 44.35 & 7.50 & & May 1994 \\
\hline \multicolumn{6}{|l|}{ Sardinia } \\
\hline Pietru & Sal & 40.75 & 8.98 & 6 & December 1992 \\
\hline Santo Antonio & $\mathrm{Sa} 2$ & 40.82 & 9.11 & 3 & December 1992 \\
\hline \multicolumn{6}{|l|}{ Sicily } \\
\hline Ficuzza & Sil & 37.92 & 14.40 & 3 & January 1994 \\
\hline Grateri & $\mathrm{Si} 2$ & 37.95 & 13.36 & 3 & January 1994 \\
\hline \multicolumn{6}{|l|}{ Portugal } \\
\hline Setubal & P1 & 38.58 & -8.65 & & March 1996 \\
\hline Vale de Guarda & $\mathrm{P} 2$ & 38.96 & -9.27 & 3 & March 1996 \\
\hline \multicolumn{6}{|l|}{ Spain } \\
\hline Torla & S4 & 42.68 & 0.18 & 2 & May 1995 \\
\hline Alcoy & S7 & 38.70 & -0.46 & 20 & May 1995 \\
\hline Coto Doñana & \$8 & 37.08 & -6.49 & & January 1996 \\
\hline Trujillo & S9 & 39.47 & -5.83 & 3 & March 1996 \\
\hline \multicolumn{6}{|l|}{ Balearic Islands } \\
\hline Lluc & Ma1 & 39.79 & 2.87 & 3 & October 1997 \\
\hline Alamédra & Ma2 & 39.73 & 2.82 & 6 & October 1997 \\
\hline \multicolumn{6}{|l|}{ Morocco } \\
\hline Cap Spartel & M1 & 35.79 & -5.92 & 7 & March 1997 \\
\hline Azrou & M2 & 33.40 & -5.17 & 4 & March 1997 \\
\hline Ifrane & M3 & 33.48 & -5.02 & 2 & March 1997 \\
\hline Djebel Tichtrar & M4 & 33.46 & -4.86 & 3 & March 1997 \\
\hline Azgour & M5 & 31.42 & -7.52 & 2 & March 1997 \\
\hline \multicolumn{6}{|l|}{ Tunisia } \\
\hline Zaghouan & Tu1 & 36.40 & 10.14 & 6 & January 1995 \\
\hline Ain Draham & Tu2 & 36.78 & 8.69 & 4 & January 1995 \\
\hline
\end{tabular}

was constructed from the matrix of the $p$ values. The robustness of the inferences was assessed through bootstrap analysis (1000 replicates) (Treecon program version 1.2; Van De Peer and De Wachter 1996).

\section{Results}

A total of 130 wood mice representing 29 populations from the western part of the Mediterranean basin were analysed (Table 1). Fifty-four different fragments were obtained after digestion by HaeIII and RsaI. Data concerning different fragment sizes are available upon request from J.R.M.

A total of 53 different haplotypes were obtained from the animals examined (29 for HaeIII and 40 for RsaI, not including those of $A$. flavicollis). Some of these are illustrated in Fig. 3. No difference was observed in the total lengths of the mtDNA as recalculated after interpretation of each rest tion pattern, a potential problem raised by Tegelström Jaarola (1989). The neighbour-joining tree (Fig. 4) shows the outgroups are well separated from all the other anin at a high level of divergence $(>7 \%)$ and robustly (boots value $=100 \%$ ). The other haplotypes are distributed wi the three distinct clusters already described for western Eur i.e., western (Spain, France, Balearic Islands), Tyrrheni Balkan (Italy, Corsica, and Sardinia and a Bulgarian haplot Be76), and Sicilian groups (Michaux et al. 1996a, 19 $1998 a, 1998 b$ ). In Tunisia, four different haplotypes v found, one of these (A054) being the only one presen Morocco. These haplotypes, which are very similar to 6 other, form a well-defined subgroup (bootstrap value $=9$ inside the western lineage (Fig. 4), an observation the confirmed by cytochrome $b$ gene sequencing results (J.R 
Fig. 3. Restriction patterns after HaeIII endonuclease digestion of wood mouse mtDNA. Patterns and localities, respectively, are as follows: lane 1: A, I1; lane 2: A, I5; lanes 3 and 4: W, Si1; lanes 5 and 6: Ao, Tu2; lane 7: Ao, Tu1; lane 8: Aq, S7. The leftmost lane is phage $\lambda$ DNA digested by $B g l$ I to produce frag ment size markers, some of them indicated by a black triangle on the left (from top to bottom: 1650, 790, 562, and $366 \mathrm{bp}$ ).

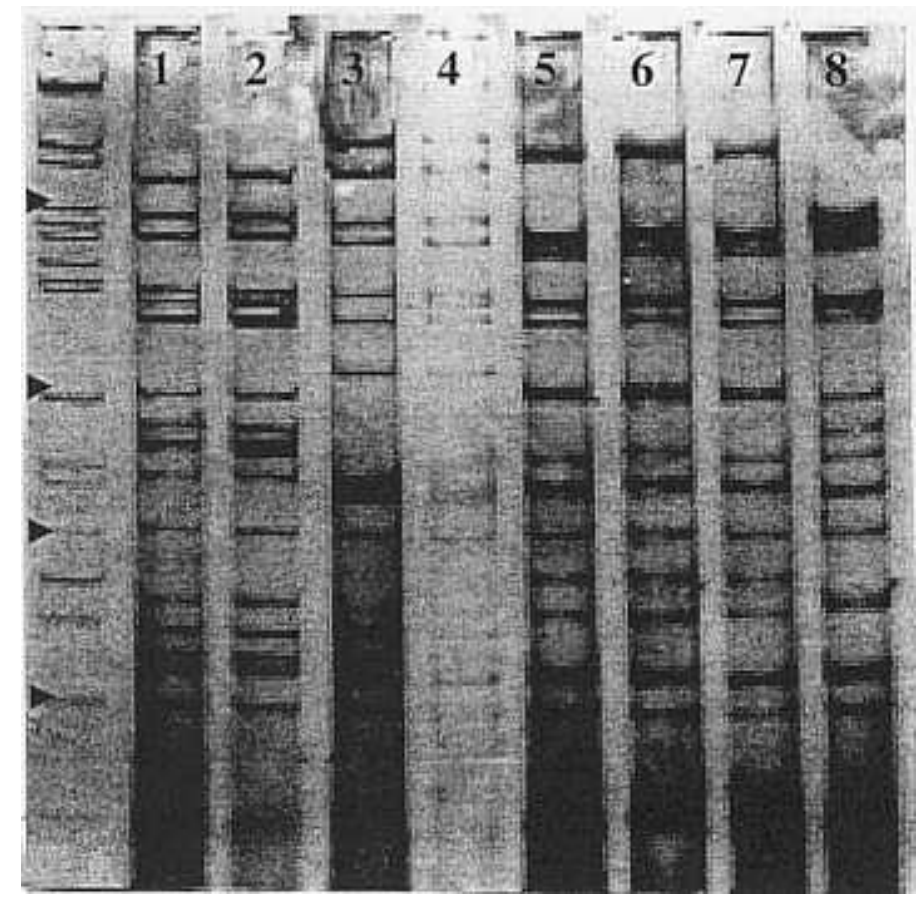

unpublished data). The mean intragroup divergence level between haplotypes is $0.76 \%$, significantly lower ( $t$ test, $p=$ 0.05 ) than the phylogenetically related continental groups (France: $1.19 \%, p=0.01$; Spain: $0.96 \%, p=0.046$ ).

The phylogenetically nearest western haplotype (Bg63) has been observed in a mouse from central Spain (S9). Its genetic distance from the African Ao54 haplotype reaches $1.44 \%$, a divergence level that is usually observed among animals from the same trapping site (e.g., 1.29\% between Aq60 and Ar61 from S7 (Alcoy); other examples appear in Michaux et al. 1996a).

\section{Discussion and conclusions}

Our data show that North African wood mice belong to the A. sylvaticus group, which is well separated from the outgroup A. flavicollis. Furthermore, they are part of a welldefined lineage linked to the western lineage of mtDNA haplotypes and distinct from the Sicilian and TyrrhenianBalkan ones. The present results are in accordance with those of Gemmeke et al. (1987), who found that the A allele of transferrin is shared by Tunisian and western European (Portugal, Spain, France, Germany) mice, whereas the animals of the Tyrrhenian-Adriatic region (Italy, Sardinia, Croatia) are characterized by the presence of the $B$ and $C$ alleles. These observations strongly suggest that North African wood mouse populations might have a southwestern European origin. Indeed, there are no genetic affinities between them and either the Sicilian, Italian, or Balkan populations. Therefore, the first three colonization hypotheses (Fig. 1) are not supported. The phylogenetically nearest European haplotype,
Bg63, was found in the central part of the Iberian Peninsula. This observation suggests that the introduction probably occurred via the Strait of Gibraltar.

From this perspective, the presence of two subspecies of L. taschenbergi in North Africa is surprising. Their passage probably happened after their differentiation, which could have occurred during a Quaternary glacial episode (Beaucournu 1976). Consequently, it can be assumed that their presence in North Africa is the result of a double immigration from Europe. The presence of $L$. $t$. amitina is easily understood. Indeed, the flea was probably introduced from Spain with the wood mice.

The presence of $L$. $t$. calamana is more complicated and two hypotheses can be proposed. (1) This subspecies arrived recently on secondary hosts such as the house mouse and black rat, which invaded the Mediterranean realm during the Bronze Age and Iron Age, respectively (Auffray et al. 1990; Audoin-Rouzeau and Vigne 1994). However, based on this hypothesis, the western flea, $L$. $t$. amitina, which probably arrived in North Africa earlier, could have had time to invade the eastern regions, considering the absence of its principal competitor. Therefore, we should find both subspecies in Tunisia, which is not the case. (2) Leptopsylla taschenbergi calamana could have reached northeastern Africa with its usual host, A. sylvaticus. In this case, the absence of Sicilian or Tyrrhenian mtDNA haplotypes could reasonably be explained by intraspecific competition. Once established, the resident mice could have been reluctant to accept new invaders, developing unusual aggressiveness towards the newcomers and excluding them from the reproductive process (Granjon and Cheylan 1989). Another hypothesis involves the progressive elimination of the foreign mtDNA lineages by assortative matings. In the house mouse, mate-choice decisions depend not only on behaviour (preference for the dominant male) but also on genetic determinants (Lenington 1982; Laukaitis et al. 1997). Similarly, the absence of Tyrrhenian haplotypes in Sicily has also been reported (Michaux et al. $1998 \mathrm{~b}$ ), despite the narrow Strait of Messina (3 km).

The analyses reveal also that the North African lineage ranges all over the African distribution area of the wood mouse, i.e., from Morocco to Tunisia and probably throughout Algeria (mtDNA data are lacking for that country). This great similarity throughout North Africa was already highlighted by the allozymic study of Filippucci (1992) (Nei's distance, $D=0.008$ ). However, all her North African samples were collected in the Mediterranean biome and not in the mountains where the above-mentioned subspecies have been described. Nevertheless, the present data confirm a lack of variability, even between animals that were caught either at long distances from each other or in the loci typici of the North African subspecies, i.e., where some genetic differences could a priori be expected.

From a taxonomic point of view, the present data reinforce the opinion of Kowalski and Rzebik-Kowalska (1991), who, based on morphological characters, invalidated the $\operatorname{taxa} A$. s. ifranensis Saint Girons and Van Bree, 1963 and A. s. rufescens Saint Girons and Van Bree, 1963 and considered that the wood mouse was monotypic throughout the region. In fact, the description of these subspecies caused some confusion, since the limits of their distribution are not clear and do not correspond to a geographic or ecoclimatic 
ᄉा!๐!s

e!̣ebing

'e!u!pues

'eo!sjoj

'시리

$$
\begin{aligned}
& \text { Z S2120011024 }{ }^{-} \nabla \\
& \text { I s1210021001f }{ }^{-} \mathrm{V}
\end{aligned}
$$
$\sqrt{00 \mathrm{I}}$

(I) (oser)zis

(I) $(8 t$ teV $)[I S$

(I) $(8 t q \nabla)$ Irs

(I) $(Z S M) \mathrm{TIS}$

(z) ( $\angle$ DOV)ZIS

(ट) $(69 \forall) \geqslant 0$

(I) $(89 \wedge \nabla) \vee D$

(†) $(6 I \nabla) L D$

(Z) (SII)

(Z) (SIHI) IO

(Z) (8IH)TO

(z) $(6 \nabla) I I$

(†) $(\angle I \nabla) S I$

(z) $(\varepsilon \forall) \mathbf{I I}$

(L) $(Z \nabla) \mathbf{I I}$.

(t) $(t \nabla) \mathbf{K I}$

(I'Z) (ZZت્త)9I'ZI

(9) (乙乙一) res

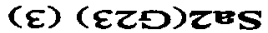

(I) $(9 \angle \odot g)$ I ng<smiles>CCOO</smiles>

$\sqrt{56}$

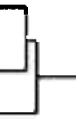

(I) $($ IgBV $\angle S$

(I) $($ IgXV) $\angle S$

(I) (t乙2) ZH

(I 'E) (LSN

(I'I) $(8 \angle x \nabla) 6 S^{\circ} \mathrm{Td}$

(Z) (O8I

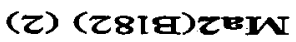

(Z) ( $\angle$ Iघ) ZEN

(I) $(\sigma \angle$ UE $)$ I BIN

(Z) $($ I 8 !

(I) $(\neg \angle F E) 85$

spue|s|

ग!ฺеәея

jebnuod

'uleds

'əoued]

(I) $(G Z I \nabla) \angle S$

(I) $(\sigma s s \nabla) \angle S$.

(†) $(6 Z u \nabla)$ tI

(z) $(6 z b \forall) \angle s$

(E) $(6 \$ b \nabla) \angle S$

(I) $(8 \mathrm{SbV}) \angle S$

(z) $(8 \leq x \vee)+s$

(I) $(\angle S B V) \angle S$

(t) $(09 b \forall) \angle s$

(I) $(\downarrow 96 \nabla)<S$

(E) $(O \angle b \forall) \angle S$

(I) $(29 b \forall) \angle S]$

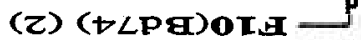

(I) (sZT)Za

(Z) (sZO)ZH

(I) $(9 Z N) Z A$

(I) (L乙T)Zs

(I) (tsdr)zne

(I) (

$(8 I: s)(t S O \forall) s^{6} \nabla^{6} \varepsilon^{4} Z^{6}$ IINSIMI

(E) (sso৮)znL

(I) $(9$ sor) InL

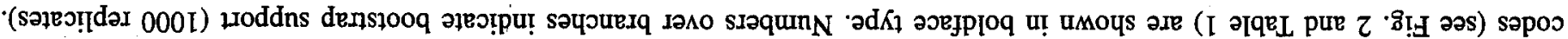

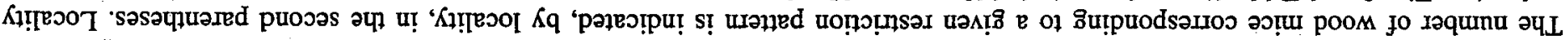

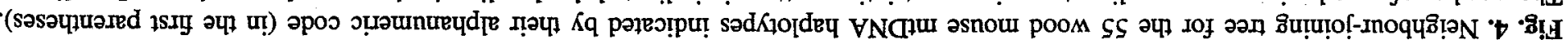


barrier. The holotype of $A$. s. rufescens was collected by G. Niethammer in Temmerkennit (Saint Girons and Van Bree $1963), 45 \mathrm{~km}$ southeast of Algiers, undoubtedly within the range of $A$. s. hayi. The range of the subspecies is said to cover also the high plateau of Algeria and the High Atlas region of Morocco, southeast of Marrakech (Saint Girons and Van Bree 1963). Although some "rufescens" individuals were caught in the region of Chaouen, Morocco (Saint Girons 1972), i.e., completely inside the range of $A$. $s$. hayi, the subspecific distinction was maintained only on the basis of the rufous colour and the large size of these animals and despite the morphological similarity to southern European wood mice (Saint Girons 1974). Reviewing the situation, Kock and Felten (1979) considered rufescens a synonym of hayi.

An estimate of the minimum divergence time between North African and southern European phylogeographic groups could indicate when the colonization of North Africa took place. A simple way is to calculate the pairwise divergence between African and Spanish haplotypes: $1.91 \pm 0.4 \%$ (mean $\pm \mathrm{SD}$ ). Another way is to consider the genetic distance between the phylogenetically nearest haplotypes, Bg63 in central Spain and Ao54 in Morocco, which is 1.44\%. Another possibility is that colonization occurred as recently as after the split between Ap54 and its sister-group (1.32\%). The latter would be true if several closely related forms were part of the founding population, hence we are seeing ancestral diversity reflected in the tree. The time needed to reach these divergence levels can be estimated at about 950000 , 710000 , and 660000 years, respectively (2\% per million years; Wilson et al. 1985), despite the possibility of rate divergence (Avise 1994). In either case the colonization event should have occurred during the Early or the early Middle Pleistocene. However, such ancient settlement is not supported by any paleontological data (Jaeger 1975; J.J. Jaeger, personal communication, 1999; Burgio 1998) and explains neither the overall low genetic variability of North African wood mice nor the presence of the same restriction pattern in all of the Moroccan animals as well as in some Tunisian ones.

Across Europe, at similar distances (e.g., from Gibraltar to the North Sea, i.e., $1800 \mathrm{~km}$ ), the genetic variability is much greater, since, for example, 72 different haplotypes have been observed in 114 European individuals (Michaux et al. 1996a, 1998a) compared with only 4 in 28 North African wood mice (this study).

The fact that the same restriction pattern is found in both Morocco and Tunisia could be due to the low resolution of the method used. In Europe, some haplotypes are shared in populations living at a considerable distance from each other $(>500 \mathrm{~km})$. However, their frequency is significantly lower than in Africa (23 mice out of 114 compared with 23 out of 28; $G$ test, $G=15.01, p<0.001$ ).

This very low genetic variability suggests that a founder effect gave rise to a genetic bottleneck. This can be explained by two hypotheses. (1) A recent colonization event involving only a few individuals occurred (Hewitt 1999), as observed in anthropogenic introductions such as in the Balearic Islands (intragroup mean genetic divergence $=0.57 \%$; Michaux et al. 1998a). In this case, the high level of genetic divergence between European and North African wood mice would be explained by the recent invasion of some European haplo- types already divergent from the other haplotypes. Indeed, refuge regions such as the Iberian Peninsula are generally characterized by a high diversity of mitochondrial types (Avise 2000) that evolved separately, sometimes over a long period. For example, the level of genetic divergence between the Spanish haplotypes Ar61 and Aq 29 or Aq 59 are 1.64 and $1.6 \%$, respectively, suggesting a separation time of $820000-800000$ years. A reverse situation (i.e., low genetic variability in Europe) has recently been observed in the greater white-toothed shrew, C. russula (J.F. Cosson, personal communication, 1999), supporting Catzeflis' (1984) opinion about the recent introduction of this species from North Africa, where the genetic variability among populations is greater. (2) There was a recent expansion from a small area of original "inoculation," in which the inoculation occurred during the Early to Middle Pleistocene, as suggested by the degree of genetic distance. But how can the fact that this founder population did not invade other North African regions during a period of at least 600000 years be explained, considering that the ecoclimatic characteristics of these regions in the Pleistocene were favourable for wood mice (Jaeger 1975; Blondel 1995)? Moreover, this hypothesis is at odds with the paleontological data (Jaeger 1975).

It is concluded that the wood mouse in North Africa originated from southwestern Europe and is probably a recent anthropogenic introduction. More samples from southern Spain would provide information about the precise location of the source of the immigrants, and data about Algeria could help to confirm the lack of genetic variability throughout the African range of the species.

\section{Acknowledgements}

This research has been supported by an Institut pour la Recherche Scientifique dans l'Industrie et l'Agronomie - Fonds pour la Recherche Scientifique dans l'Industrie et l'Agronomie fellowship to J.R.M., grants from the Fonds National de la Recherche Scientifique covering field collecting in Spain, Italy, Tunisia, and Morocco, and a Fonds de la Recherche Fondamentale et Collective grant (No. 2.4547.89). For their help in trapping or keeping the animals in captivity we are grateful to J.P. Clara, R. Fons, D. Frynta, C. Hallet, Th. Kervyn, S. Kinet, J. Ninane, F. Ronveaux, M. Santos-Reis, V. Vohralik, and L. Zanca. We are particularly indebted to Prof. J. Franchimont and his wife, Fatima, as well as to the Dean of the Faculty of Sciences, Meknès University, for facilitating our stay in Morocco, and to Prof. R.F. Matagne for his invaluable logistic help.

\section{References}

Arambourg, C. 1962. Les faunes mammalogiques du Pléistocène circumméditerranéen. Quaternaria, 6: 67-109.

Audoin-Rouzeau, F., and Vigne, J.D. 1994. La colonisation de l'Europe par le rat noir (Rattus rattus). Rev. Paleobiol. 13: 125145.

Auffray, J.-C., Vanlerberghe, F., and Britton-Davidian, J. 1990. House mouse progression in Eurasia: a palaeontological and archaeozoological approach. Biol. J. Linn. Soc. 41: 13-25.

Avise, J.C. 1994. Molecular markers, natural history and evolution. Chapman and Hall, New York. 
Avise, J.C. 2000. Phylogeography, the history and formation of species. Harvard University Press, Cambridge, Mass.

Beaucournu, J.-C. 1976. Contribution à l'étude des siphonaptères de mammifères du nord-ouest de la région méditerranéenne (France, Italie, Péninsule ibérique). Ph.D. thesis, Université de Rennes, Rennes, France.

Beaucournu, J.-C., and Launay, H. 1990. Les puces de France et du Bassin méditerranéen occidental. Faune de France, $n^{\circ} 76$. Fédération Française des Sociétés de Sciences naturelles, Paris.

Blondel, J. 1995. Biogéographie, approche écologique et évolutive. Masson, Paris

Blondel, J., and Vigne, J.-D. 1993. Space, time and man as a determinant of vertebrate diversities in the Mediterranean region. In Species diversity in ecological communities. Edited by R.E. Ricklefs and D. Schulter. Chicago University Press, Chicago. pp. 135-146.

Burgio, E. 1998. Le attuali conoscenze sui mammiferi terrestri quaternari della Sicilia. In Prima Sicilia. Alle origini della società siciliana. Edited by S. Tusa. Ediprint, Palermo. pp. 54-74.

Demesure, B., Comps, B., and Petit, R.J. 1996. Chloroplast DNA phylogeography of the common beech (Fagus sylvatica L.) in Europe. Evolution, 50: 2515-2520.

Dumolin-Lapègue, S., Demesure, B., Fineschi, S., Le Corre, V., and Petit, R.J. 1997. Phylogeography structure of white oaks throughout the European continent. Genetics, 146: 1475-1487.

Camps, G. 1990. Navigation et migrations en Méditerranée de la préhistoire à nos jours. Collioure 1983-Sète 1985. Centre National de la Recherche Scientifique, Paris. 138-156.

Castella, V., Ruedi, M., Excoffier, L., Ibanez, C., Arlettaz, R., and Hausser, J. 2000. Is the Gibraltar strait a barrier to gene flow for the bat Myotis myotis (Chiroptera: Vespertilionidae)? Mol. Ecol. 9(11): 1761-72

Catzeflis, F. 1984. Systématique biochimique, taxonomie et phylogénie des musaraignes d'Europe (Soricidae, Mammalia). Ph.D. thesis, Université de Lausanne, Lausanne, Switzerland.

Durand, J.D., Persat, H., and Bouvet, Y. 1999. Phylogeography and postglacial dispersion of the chub (Leuciscus cephalus) in Europe. Mol. Ecol. 8: 989-997.

Engelbrecht, C.C., Freyhof, J., Nolte, A., Rassmann, K., Schliewen, U., and Tautz, D. 2000. Phylogeography of the bullhead Cottus gobio (Pisces: Teleostei: Cottidae) suggest a pre-Pleistocene origin of the major central European populations. Mol. Ecol. 9: 709-722.

Filippucci, M.G. 1992. Allozyme variation and divergence among European, Middle Eastern, and North African species of the genus Apodemus (Rodentia, Muridae). Isr. J. Zool. 38: 193-218.

Filippucci, M.G., Simson, S., and Nevo, E. 1989. Evolutionary biology of the genus Apodemus Kaup 1829 in Israel. Allozymic and biometric analyses with description of a new species: Apodemus hermonensis (Rodentia, Muridae). Boll. Zool. 56: 361376.

Filippucci, M.G., Macholan M., and Storch G. 1996. Taxonomy of the genus Sylvaemus in western Anatolia-morphological and electrophoretic evidence (Mammalia: Rodentia: Muridae). Senckenb. Biol. 75(1/2): 1-14.

Gemmeke, H., Radtke, M., and Niethammer, J. 1987. Zur innerartlichen Proteinvariation bei der Waldmaus (Apodemus sylvaticus). Z. Saeugetierkd. 52: 242-247.

Granjon, L., and Cheylan, G. 1989. Le sort de rats noirs (Rattus rattus) introduits sur une île, révélé par radiotracking. C. $\mathbf{R}$. Acad. Sci. Paris Ser. III, 309: 571-575.

Groves, R.H., and Di Castri, F. 1991. Biogeography of Mediterranean invasions. Cambridge University Press, Cambridge.
Heim de Balsac, H. 1936. Biogéographie des oiseaux el mammifères d'Afrique du Nord. Bull. Biol. Fr. Belg. S No. 21.

Hewitt, G.M. 1999. Postglacial recolonization of European 1 Biol. J. Linn. Soc. 68: 87-112.

Holz, H., and Niethammer, J. 1990. Atelerix algirus (Lerebı 1840), Wanderigel. In Handbuch der Säugetiere Europas. $E$ by J. Niethammer and F. Krapp. Aula Verlag, Wiesbaden, many. pp. 65-74.

Jaeger, J.J. 1975. Les Rongeurs, du Miocène à l'actuel, en Af nord-occidentale. Ph.D. thesis, Université des Sciences et ' niques du Languedoc, Montpellier.

Kobelt, W. 1886. Die Säugetiere Nordafrikas. Zool. Gart. 27: $177,205-212,237-243$, and 312-316.

Kock, D., and Felten, H. 1979. Typen und Typus-Lokalitä Apodemus sylvaticus rufescens Saint Girons and Van Bree (Mammalia, Rodentia, Muridae). Senckenb. Biol. 60: 277.

Kowalski, K., and Rzebik-Kowalska, B. 1991. Mammals of ria. Polish Academy of Sciences, Ossolineum Publishing $\mathrm{H}$ Wroklaw.

Kurten, B. 1968. Pleistocene mammals of Europe. Weidenfel Nicolson, London.

Laukaitis, C.M., Critzer, E.S., and Karn, R.C. 1997. Sa androgen-binding protein (ABP) mediates sexual isolati Mus musculus. Evolution, 51: 2000-2005.

Lenington, S. 1982. Social preferences for partners carrying genes" in wild house mice. Anim. Behav. 31: 325-333.

Libois, R.M., and Fons, R. 1990. Le mulot des îles d'Hyère: cas de gigantisme insulaire. Vie Milieu, 40: 217-222.

Michaux, J., Filippucci, M.G., Libois, R.M., Fons, R., and Ma R. 1996a. Biogeography and taxonomy of Apodemus sylv (the woodmouse) in the Tyrrhenian region: enzymatic vari and mitochondrial DNA restriction pattern analysis. HeI 76: 267-277.

Michaux, J., Libois R.M., and Fons, R. 1996b. Différenc génétique et morphologique du mulot, Apodemus sylvaticus le bassin méditerranéen occidental. Vie Milieu, 46: 193-2

Michaux, J., Libois, R., Ramalhinho, M.G., and Maurois, C. 1 On the mtDNA restriction patterns variation of the Iberian mouse (Apodemus sylvaticus). Comparison with other Mediterranean populations. Hereditas, 129: 187-194.

Michaux. J., Sarà, M., Libois, R., and Matagne, R. $1998 b$. woodmouse (Apodemus sylvaticus) of Sicily a distinct sp Belg. J. Zool. 128: 211-214.

Nei, M., and Li, W.H. 1979. Mathematical model for studyir netic variation in terms of restriction endonucleases. Proc. Acad. Sci. U.S.A. 76: 5269-5273.

Reumer, J.W.H., and Sanders, E.A.C. 1984. Changes in vert fauna in Menorca in Prehistoric and Classical time Saeugetierkd. 49: 321-325.

Sarà, M., and Casamento, G. 1995. Morphometrics of the mouse (Apodemus sylvaticus, Mammalia, Rodentia) in the iterranean. Boll. Zool. 62: 313-320.

Saint Girons, M.C. 1972. Le genre Apodemus Kaup 1829, au I Z. Saeugetierkd. 37: 362-371.

Saint Girons, M.C. 1974. Rongeurs, lagomorphes et insect du Massif du Toubkal (Haut Atlas marocain). Bull. Soc Nat. Maroc, 54: 55-59.

Saint Girons, M.C., and Van Bree, P.J.H. 1963. Recherches répartition et la systématique de Apodemus sylvaticus (Lir 1758) en Afrique du Nord. Mammalia, 26: 478-488.

Saint Léger, J. 1931. A key to the families and genera of A Rodentia. Proc. Zool. Soc. Lond. 110: 957-959. 
Sanges, M., and Alcover, J.A. 1980. Noticia sobre la microfauna vertebrada holocenica de la Grotta Su Guanu o Gonagosula (Oliena, Sardenya). Endins, 7: 57-62.

Santucci, F., Emerson, B.C., and Hewitt, G.M. 1998. Mitochondrial DNA phylogeography of European hedgehogs. Mol. Ecol. 7: 1163-1172.

Taberlet, P., Fumagalli, L., Wust-Saucy, A.G., and Cosson, J.F. 1998. Comparative phylogeography and postglacial colonization routes in Europe. Mol. Ecol. 7: 453-464.

Tegelström, H., and Jaarola, M. 1989. Genetic divergence in mitochondrial DNA between the wood mouse (Apodemus sylvaticus) and the yellow necked mouse (Apodemus flavicollis). Hereditas, 111: 49-60.

Thaler, L. 1973. Nanisme et gigantisme insulaires. Recherche, 37: 741-750.

Van De Peer, Y., and De Wachter, R. 1996. Construction of evolutionary distance trees with TREECON for Windows: accounting for variation in nucleotide substitution rate among sites. Comput. Appl. Biosci. 13: 227-230.

Vigne, J.D. 1983. Le remplacement des faunes de petits mammifères en Corse lors de l'arrivée de l'homme. C. R. Soc. Biogeogr. 59: 41-51.

Vigne, J.D. 1994. Les transferts anciens de mammifères en Europe occidentale : histoire, mécanismes et implications dans les sciences de l'homme et les sciences de la vie. In Colloques d'Histoire des Sciences zoologiques. Vol. 5. Des animaux introduits par l'homme dans la faune de l'Europe. Edited by L. Bodson. Université de Liège, Liège, Belgium. pp. 15-38.

Wilson, A.C., Cann, R.L., Carr, S.M., George, M., Gyllensten, U.B., Helm-Bychowski, K.M., Higuchi, R.G., Palumbi, S.R., Prager, E.M., Sage, R.D., and Stoneking, M. 1985. Mitochondrial DNA and two perspectives on evolutionary genetics. Biol. J. Linn. Soc. 26: 375-400. 